\title{
Relationship between tissue mobilization and storage in the rat*
}

\author{
BY CHRISTIANI JEYAKUMAR HENRY ${ }^{1} \dagger$, PHILIP R. PAYNE ${ }^{2}$ \\ AND AMAL GHUSAIN-CHOUEIRI ${ }^{1}$ \\ ${ }^{1}$ School of Biological and Molecular Sciences, Oxford Brookes University, Gipsy Lane, Oxford OX3 OBP \\ ${ }^{2}$ Human Nutrition Unit, London School of Hygiene and Tropical Medicine, Taviton Street, \\ London WCIH OBT
}

(Received 23 August 1996-Revised 16 December 1996-Accepted 16 January 1997)

\begin{abstract}
The amount of energy mobilized or stored as protein, expressed as a proportion of the total energy stored or mobilized (defined as the $P$ ratio, Payne \& Dugdale, 1977), was investigated in the young male (rapid growth) and adult female (slow growth) rat. Energy mobilization was induced by a 3 d fast and the changes in body content of fat and lean tissues were used to estimate the fasting $P$ ratio $\left(P_{\text {fast }}\right)$. Tissue storage was subsequently effected by $17 \mathrm{~d}$ of refeeding and the corresponding ratio $\left(P_{\text {refed }}\right)$ was calculated from the amounts of lean and fat tissue regained. The same experimental protocol was used for measuring $P_{\text {fast }}$ and $P_{\text {refed }}$ in weanling $(30 \mathrm{~d})$ and adult (130 d) rats. Weightmatched individuals were assigned to three groups. All animals in group 1 were killed at the beginning of the experiment. Animals in group 2 were fasted for $3 \mathrm{~d}$ and then killed. Group 3 animals were first fasted for $3 \mathrm{~d}$, then had free access to a stock diet for a further $17 \mathrm{~d}$ before being killed. During fasting, a close linear relationship was found between weight change and body energy changes $(r \mathbf{0 . 9 8 5}$, and $r \mathbf{0 . 9 2}, P<0.001$ for weanlings and adult rats respectively) and between carcass $\mathrm{N}$ loss and urinary $\mathrm{N}$ loss $(r \mathbf{0 . 9 3 3}, P<0.001)$. These relationships were used to estimate the body energy and $N$ content of each animal at the end of the initial fasting period. Hence, both $P_{\text {fast }}$ and $P_{\text {refed }}$ values could be calculated for all individuals at both ages. When $P_{\text {fast }}$ and $P_{\text {refed }}$ were calculated for adult rats, the mean values were similar (0.138 (SE 0.002) and 0.130 (SE 0.006) respectively). Individually, the $P_{\text {fast }}$ and $P_{\text {refed }}$ values were correlated $(r 0.54, P=0.058)$. In weanling rats, the mean $P_{\text {refed }}$ value was about 2.5 times the $P_{\text {fast }}(0.421$ (SE 0.0113) v. 0.156 (SE 0.004)). Despite the differences in $P_{\text {fast }}$ and $P_{\text {refed }}$, the individual values were again correlated $(r 0.668$, $P<0.05$ ). These results support the suggestion made by Payne \& Dugdale (1977), that particular $P$ ratio values are characteristic of individuals and describe the extent to which protein is mobilized or stored during fasting or refeeding. These observations are discussed in relation to the predictions made by the Payne-Dugdale model.
\end{abstract}

Energy-protein mobilization: Energy-protein storage: $P$ ratio

At the present time there is still no general consensus on the way in which body weight is regulated in adults. Garrow $(1974,1978)$ suggested that the extensive accumulation of experimental data relating to body-weight regulation, could equally well be explained by any one of three main hypotheses: the 'set point', the 'cognitive control' and the 'dynamic equilibrium' or 'buffered' control theories. Conceptually, both the set point and the cognitive control theories require the existence in the body of a fixed reference or a target weight, against which the actual weight is constantly monitored. The dynamic equilibrium on the other hand requires no such control.

Payne \& Dugdale (1977) described a computer model of weight regulation, which stimulates well the regulation of adult body weight, without depending on a 'set point'

* Part of this work has been reported in abstract form at the Nutrition Society Summer Meeting, Coleraine, 1996.

$\uparrow$ For reprints. 


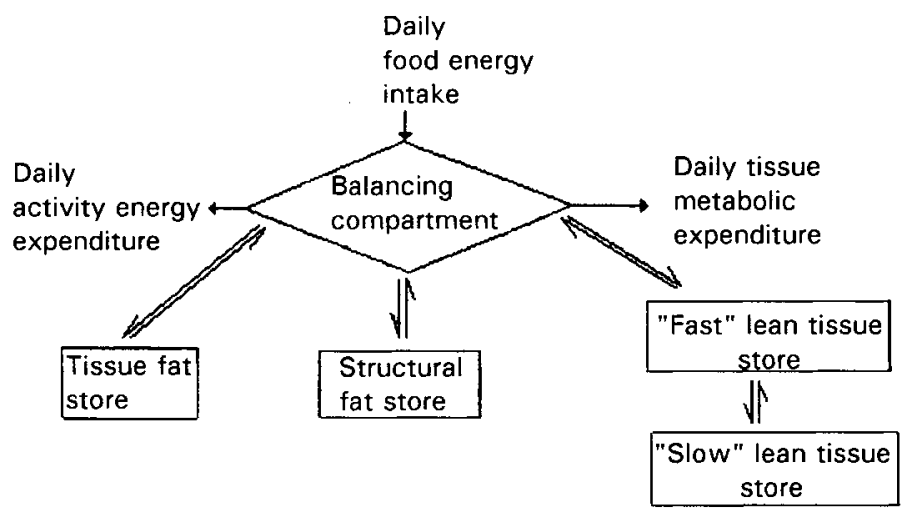

Fig. 1. Compartmental model for the regulation of body weight and its composition (taken from Payne \& Dugdale, 1977).

mechanism. The model represents the energy content and BMR of the body in terms of the sizes and rates of energy metabolism $/ \mathrm{kg}$ tissue, of four compartments (Fig. 1). Starting from a specified initial set of compartment weights, together with daily rates of energy intake and expenditure on physical activity, the model calculates a series of day-by-day incremental changes of the compartment energy content. The output of the model is a description of the time-course of changes in body weight, body fat and resting metabolic rate which result from any change of energy intake or physical activity.

In order to calculate these increments, the model uses a set of transfer functions, which specify how any positive energy balance for each day is distributed amongst the compartments and stored in the form of fat or lean tissue. A similar set of functions determines how any negative balance is met by mobilizing the necessary amounts of fat and lean tissue from each compartment. In the standard configuration of the model, it is assumed that the proportion in which energy is partitioned between protein and fat, during deposition, is identical to that which results from mobilization, and that any particular value of that ratio which is chosen remains a fixed characteristic for the individual whose weight regulation is being simulated. Partly as a matter of convenience in writing the transfer functions, this ' $P$ ratio' was defined as that proportion of any incremental amount of energy either mobilized or deposited, which is stored as protein. That is to say, $\Delta \operatorname{Pr} /$ $(\Delta \mathrm{Pr}+\Delta \mathrm{F})$ where $\Delta \mathrm{Pr}$ and $\Delta \mathrm{F}$ are incremental amounts of protein and fat deposited or mobilized, expressed as equivalent amounts of metabolizable energy (ME). It is evident that the value chosen for the $P$ in any particular run of the model, will determine the composition of any gain or loss of body weight. Low values $(\mathrm{P}$ ratio $<0.05)$ typify the kind of individual who stores energy largely in the form of fat, and high values ( $\mathrm{P}$ ratio $>0.2)$, describe individuals who store surpluses predominantly as lean tissue. If the model is run repeatedly, using a range of different $P$ values, in order to simulate episodes of weight loss followed by recovery, the end results will describe a 'population' of individuals, of different constitutional types, amongst whom there is an inverse relationship between $P$ ratio and the final percentage of total body fat.

It was an important feature of the model as originally described by Payne \& Dugdale (1977), that when used to simulate very long time periods (years), the degree to which body composition and weight remain within realistic boundaries, depends on the closeness to which equality is specified for the $P$ ratios used for calculating deposition and mobilization of tissues. However, this identity is not a necessary assumption: it is a simple matter to 
insert different values into the transfer functions, so as to represent $\mathrm{P}$ ratios determined during negative energy balance $\left(P_{\text {fast }}\right)$ and those determined during positive balance ( $\mathrm{P}_{\text {refed }}$ ). If the model is run with $\mathrm{P}_{\text {refed }}$ set at a value lower than that of $\mathrm{P}_{\text {fast }}$, total body fat percentage will rise with each episode of weight loss followed by recovery, or vice versa.

Notwithstanding the fact that the $\mathrm{P}$ ratio was originally defined in such a way as to facilitate the definition of the functions used in the simulation model, interest in the biological significance of the concept has increased over time, and it is now felt important to test the hypothesis regarding inter- and intra-individual variability by direct measurements, as a way of gaining a better understanding of the mechanisms governing energy regulation and body composition.

\section{Inter-individual differences in $P$ ratio}

Payne \& Dugdale (1977) noted that the shapes of the distributions of P values calculated for the participants in the Minnesota Experiment on semi-starvation (Keys et al. 1950), together with those estimated from the weight and fat losses occurring as a result of weight reduction of obese subjects and treatment of some exceptionally thin people, are consistent with the hypothesis that the values reflect genetic differences in the regulatory responses of individuals having 'fat' or 'lean' constitutions. Since then, several authors (Forbes, 1987; Henry et al. 1988; Dulloo et al. 1996) have added strength to this proposition. For example, it is now generally accepted that there is an inverse relationship between initial adiposity before fasting (Prentice et al. 1991) or repletion, and the ratio fat:lean tissues subsequently lost or gained. Forbes (1987), in a review of diet-induced weight changes in human subjects showed that provided that the first few days are excluded (because of large changes in fluid balance), the data from 164 subjects are well described by the relationship $\Delta \mathrm{LBM} / \Delta \mathrm{F}=10 \cdot 4 / \mathrm{F}$, where $\Delta \mathrm{LBM}$ is the incremental change observed in lean body mass, $\Delta \mathrm{F}$ is the corresponding increment of fat, and $\mathrm{F}$ is the initial body fat content. Evidently, there is a formal relationship between $\Delta \mathrm{LBM} / \Delta \mathrm{F}$ and $\mathrm{P}$. In fact, if we assume that protein is a constant proportion of $\mathrm{LBM}$, then $\Delta \mathrm{LBM} / \Delta \mathrm{F}$ will be proportional to $\mathrm{P} /(1-\mathrm{P})$. Henry et al. (1988) analysed the data from classical studies on starvation of normal adult human subjects to show that differences in $P$ ratio between individuals become established after the first few days and then remain unchanged throughout prolonged periods of starvation. Dulloo et al. (1996) extended the analysis of the data on subjects of the Minnesota experiment. They calculated the $\mathrm{P}$ value for each individual during both the weight reduction and rehabilitation phases and concluded that the $P$ value of each individual, operating during the early phase of semi-starvation, is a reflection of a 'fat-lean compartmental memory', which pre-determines the composition of tissue subsequently either lost or gained during later dietary treatment. They further concluded that the range of $P$ values found amongst groups of normal individuals is sufficient to account for the wide variation of lean and fat deposition observed during nutritional rehabilitation of malnourished patients.

\section{Intra-individual changes in $P$ ratios}

Whilst there is strong experimental evidence for the constancy of $\mathrm{P}$ ratios in adult subjects, at least over a period of months, and despite quite severe dietary treatments, this is unlikely to hold true throughout the whole of life. In particular, major changes in the body proportions of fat and lean tissues are known to happen during fetal development, infancy and childhood. These imply significant changes of the $\mathrm{P}$ ratio throughout growth. Dugdale 
\& Payne (1975) used a compilation of data on the directly and indirectly determined chemical composition of male subjects, to estimate mean values for the proportions of fat and lean from conception up to 16 years of age. These data suggest that low $P$ values at birth and before weaning, i.e. characteristic of fat deposition, are followed by successive cycles of high values (up to 0.5 ), consistent with the deposition primarily of lean tissue, at ages corresponding to the attainment of maximum growth velocity, first in infancy, then at adolescence. These maxims are followed by a steady fall towards the average value for adults of approximately $0 \cdot 15$. Such age-related changes are very rapid, posing a technical challenge as far as measurement is concerned and giving rise to problems of interpretation of studies, especially as those reported below, using small, fast-growing animals. There is, as yet, no information about the effect of senescence. It might be expected that $P$ values will increase during the final years of life, which tend to be characterized by negative energy balance and sustained loss of body weight.

In addition to these age-related changes, Dulloo et al. (1994) have speculated that the relatively increased rate of fat repletion sometimes observed as a 'compensatory' pattern during recovery growth of previously starved rats, should imply that $\mathrm{P}$ values measured during repletion $\left(\mathrm{P}_{\text {refed }}\right)$ will generally be found to be lower than those measured during fasting $\left(\mathrm{P}_{\text {fast }}\right)$.

The animal experiments reported here were designed to generate more data regarding these aspects of variability. The effects of age were studied by repeated measurements in young rats and in mature female animals. Intra-individual differences were observed by immediately following measurements of $\mathrm{P}_{\text {fast }}$ by those of $\mathrm{P}_{\text {refed }}$ during subsequent recovery.

\section{MATERIALS AND METHODS}

\section{Animals and diets}

Measurement of $P_{\text {fast }}$ and $P_{\text {refed }}$ in weanling rats. Male Sprague-Dawley rats (A. Tuck \& Sons Ltd, Beeches Road, Battles Bridge, Essex), $21 \mathrm{~d}$ old, were fed on a stock diet (R \& M no. 3 breeding diet, Lillico \& Sons, Wanham Mills, Betchworth, Surrey) for $9 \mathrm{~d}$. At $30 \mathrm{~d}$ of age (start of experiment) twenty-nine weight-matched animals (105 (SE 0.3)g) were assigned to any one of three groups: 1,2 or 3 . Group 1 (eight rats) were killed at the start of the experiment, for an initial estimate of carcass energy and $\mathrm{N}$ content. Group 2 (ten rats) were fasted for $3 \mathrm{~d}$ and then killed, and carcasses used to measure energy and $\mathrm{N}$ content. Group 3 (eleven rats) were also fasted for $3 \mathrm{~d}$, but were placed in individual metabolic cages. Urine was collected quantitatively over $3 \mathrm{ml} 1 \mathrm{M}-\mathrm{H}_{2} \mathrm{SO}_{4}$. At the end of the fasting period rats from group 3 were weighed, transferred back to individual plastic cages, and refed on the stock diet for $17 \mathrm{~d}$. During the refeeding period food intake and faecal losses were carefully measured. All the animals in group 3 were killed aged $50 \mathrm{~d}$ and carcasses analysed for energy and $\mathrm{N}$ contents.

Measurement of $P_{\text {fast }}$ and $P_{\text {refed }}$ in adult rats. Twenty-one female Sprague-Dawley rats aged 15 weeks $(105 \mathrm{~d}$ ) and weighing 221 (SE 1.1) g were fed on stock diet for $25 \mathrm{~d}$. Female rats were specifically chosen for this study because they attain, and maintain, a stable body weight much more readily than male rats (Donaldson, 1915). At $130 \mathrm{~d}$ of age these were assigned to three closely weight-matched groups A, B or C (248 (SE 1.2) g). In a similar design to the experiment described earlier, group A (four rats) were killed on day 0. Group B (four rats) were fasted and then killed $3 \mathrm{~d}$ later (aged 133d). Group C (eight rats), were also fasted for $3 \mathrm{~d}$ then fed on a stock diet for $17 \mathrm{~d}$, before being killed at $150 \mathrm{~d}$ of age. 
Experimental animals were always individually housed in plastic wire-bottomed cages except for the $3 \mathrm{~d}$ fast period, when they were transferred to metabolic cages. They had free access to water at all times. Body weight and food intake were measured three times per week. Rats were kept in a room maintained at $28 \pm 2^{\circ}$, with a $12 \mathrm{~h}$ light-dark cycle. Animals were killed by chloroform inhalation and carcasses and faeces stored at $-40^{\circ}$ until analysed. Urine samples were diluted with water and analysed within $24 \mathrm{~h}$ of collection.

\section{Analytical methods}

Nitrogen and energy content of carcass, urine and faeces. Rat carcasses (including the gut) were dried in an oven at $95^{\circ}$ to a constant weight, then individually macerated. Samples of urine, faeces and the finely minced carcass were analysed for $\mathrm{N}$ content using the Kjeldahl method (Bradstreet, 1965). The gross energy (GE) value of dried samples (carcass, diet or faeces) was determined using ballistic bomb calorimetry, according to the method described by Miller \& Payne (1959).

Changes in body energy and protein during fasting and refeeding. The groups of animals matched for age and body weight were killed on days 0,3 and 20 of the study. These rats were considered to be representative samples of the same experimental population measured at the three points (Rothwell \& Stock, 1981). Incremental changes in composition with time were calculated by differences between groups. Body energy and protein loss on starvation could therefore be determined from the differences between carcasses of groups 1 and 2, analysed on days 0 and 3 (comparative carcass method, Swift $\&$ French, 1954). Body-weight and body-fat gains on refeeding were taken as differences between days 3 and 20 .

Calculation of $P_{\text {fast }}$ and $P_{\text {refed. }}$. The $\mathrm{P}$ ratios were calculated by converting $\mathrm{N}$ loss or gain to equivalent amounts of $\mathrm{ME}$, and expressing these as a proportion of the total change of carcass energy. For the comparison of fasting and refed values in individual animals in groups 3 (weanlings) and $\mathrm{C}$ (adults), urinary $\mathrm{N}$ output was used as a measure of bodyprotein loss. The $\mathrm{N}$ gain or loss was converted to protein energy using the conventional factor $6.25 \mathrm{~g}$ protein $/ \mathrm{g} \mathrm{N}$ and $16.72 \mathrm{~kJ} \mathrm{ME} / \mathrm{g}$ protein. The ME equivalent of the carcasses was calculated from GE by subtraction of the amount which would have been unavailable due to the incomplete oxidation of protein (Kleiber, 1975), estimated by multiplying carcass $\mathrm{N}$ content by the factor $5.016 \mathrm{~kJ}$. Thus:

$$
\mathrm{P}_{\text {fast }} \text { or } \mathrm{P}_{\text {refed }}=\frac{\text { protein energy }(\mathrm{kJ}, \text { loss or gain })}{\text { carcass energy }(\text { loss or gain })-(\mathrm{N} \times 5.016 \mathrm{~kJ})}
$$

where: protein energy $(\mathrm{kJ})=\mathrm{N}$ (loss or gain) $\times 6.25 \times 16.72 \mathrm{~kJ}$,

5.016 is the inevitable loss of protein energy due to incomplete protein oxidation, 6.25 is the factor used to convert $\mathrm{N}$ to protein, and 16.72 is the factor used to convert protein to $\mathrm{kJ}$ (ME).

Validation of comparative carcass technique. Body energy changes were observed to be linearly related to body-weight change (Fig. 2). In addition, the same regression line describes the relationship for both the pre- and post-fasted animals to a high degree of fit:

body energy $(\mathrm{kJ})$ for weanling rats $=6.64 \mathrm{~W}-81.85(r 0.985, P<0.001)$, 


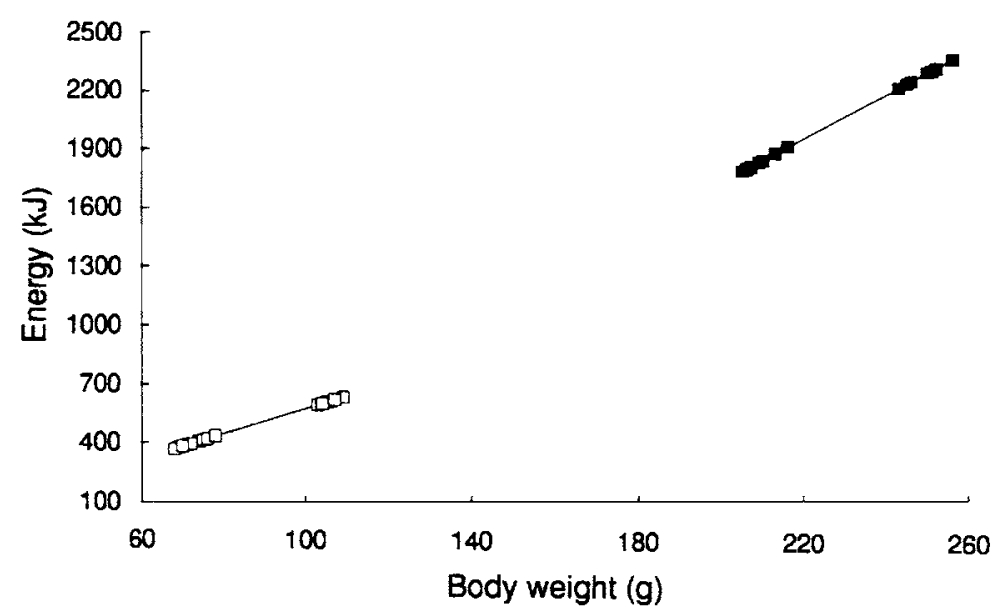

Fig. 2. Relationship between body weight and energy content in weanling ( $\square$ ) and adult ( $\square$ ) rats before and after a $3 \mathrm{~d}$ fast ( $r 0.985, P<0.001$ for weanling rats; $r 0.92, P<0.001$ for adult rats).

and

body energy $(\mathrm{kJ})$ for adult rats $=11.51 \mathrm{~W}-556(r 0.92, P<0.001)$, where $\mathrm{W}$ is body weight.

Moreover, this method of estimating energy is known to compare favourably with the respiratory exchange technique (Swift \& French, 1954). These regression equations were used to estimate the individual body energy contents of the animals in groups 3 and $\mathrm{C}$, which were refed at 33 and $133 \mathrm{~d}$ respectively and hence were not available at these ages for analysis by the comparative carcass technique. These indirect assessments have a probable error of 3.8 (SE 0.78 ) \% for weanling and 4.2 (SE 0.80 ) \% for adult rats.

Validity of using fasting urinary nitrogen loss to calculate nitrogen loss. The body $\mathrm{N}$ changes on starvation, calculated by the comparative carcass method, were compared with those calculated from urinary $\mathrm{N}$ excretion, as a check on its validity. A close linear relationship was found between bodyweight and carcass $\mathrm{N}$ (Fig. 3):

carcass $\mathrm{N}$ for weanling rats $=0.012 \mathrm{~W}+1.344(r 0.933, P<0.001)$, where $\mathrm{W}$ is body weight $(\mathrm{g})$.

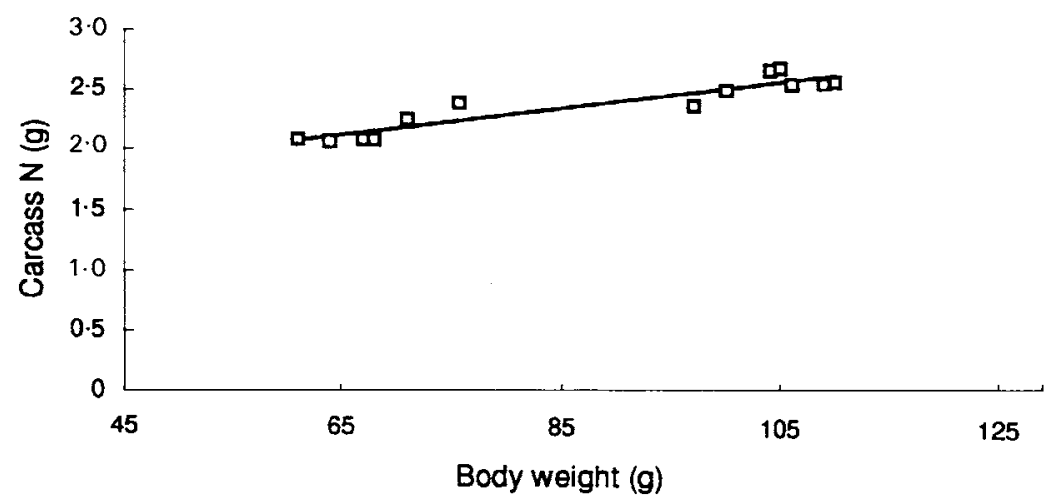

Fig. 3. Relationship between body weight and carcass nitrogen in weanling rats before and after a $3 \mathrm{~d}$ fast $(r 0.933$, $P<0.001$ ). 
Using this equation, the mean $\mathrm{N}$ loss during fasting was estimated from the mean change in body weight and found to be 389 (SE 9.9$) \mathrm{mg}$. The fasting urinary $\mathrm{N}$ loss, measured during the same period was 310 (SE 11.7) $\mathrm{mg}$, a value $80 \%$ of that predicted by the comparative carcass method. This degree of discrepancy is to be expected as the comparative carcass method of calculating $\mathrm{N}$ loss takes account of all losses, including faeces, hair, and other integumental losses. The experimentally observed $\mathrm{N}$ loss due to faecal and hair losses in rats has been reported to be 18-20\% of total $\mathrm{N}$ loss during fasting (Njaa, 1963).

The linear regression relationship between carcass $\mathrm{N}$ loss and urinary $\mathrm{N}$ loss was used to estimate the amount of body energy loss accounted for by protein by each individual animal in groups 3 and $\mathrm{C}$ at the end of the initial fasting periods.

\section{Statistical analysis}

Statistical differences were assessed using Student's paired and unpaired $t$ tests as indicated. Results are expressed individually or as the mean with its standard error. Regression analysis was also used where appropriate.

\section{RESULTS}

\section{Weanling rats}

At $30 \mathrm{~d}$ of age, a $3 \mathrm{~d}$ fast resulted in the loss of $32 \%$ of the initial body weight (106 (SE $0.5)$ g, Fig. 4). The extent of carcass energy loss (34\%) during fasting was of the same order as that in body weight (Table 1). The calculated $\mathrm{N}$ loss was about $12 \%$ of total body $\mathrm{N}$ before fasting. On refeeding, the group 3 weanling animals showed rapid recovery, regaining the lost weight in a further $3 \mathrm{~d}$ (Fig. 4). This sequence of measurements provided estimates of $P$ values, at mid-point ages of $31.5 \mathrm{~d}\left(\mathrm{P}_{\text {fast }}\right)$ and $41.5 \mathrm{~d}\left(\mathrm{P}_{\text {refed }}\right)$ respectively. The $P_{\text {refed }}$ ratio was increased to about 2.5 times the $P_{\text {fast }}$, apparently the reverse of the effect suggested by Dulloo et al. (1994). The $\mathbf{P}_{\text {fast }}$ and $P_{\text {refed }}$ in individual animals (see Table 3) were found to be significantly correlated $(r 0.668, P<0.05$, Fig. 5$)$. In addition, the individually calculated gain in percentage body fat ((carcass energy-protein energy) $\times 100)$ was found to be inversely related to the $P_{\text {fast }}$ value $(r 0.74, P<0.01$, Fig. 6).

\section{Adult rats}

A $3 \mathrm{~d}$ fast caused about $15 \%$ weight loss in adult female rats (Fig. 4). The energy loss was about $18 \%$ of total body energy, and $\mathrm{N}$ loss only $7 \%$ (Table 2 ). On refeeding, the adult rats took about $12 \mathrm{~d}$ to regain the lost weight and after $17 \mathrm{~d}$ were slightly heavier (4.6 (SE 0.72 ) \%) than their initial (248 (SE 1.2) g) body weight. In this case, the $P_{\text {refed }}$ values were slightly (but not significantly) lower than those measured during fasting, the mean of the individual differences being $5 \%$ (Table 3). The individual $\mathrm{P}_{\text {fast }}$ and $\mathrm{P}_{\text {refed }}$ values (Fig. 5) were positively correlated $(r \quad 0.54)$, but again, this was not statistically significant $(P=0.058)$. An inverse relationship was also noted between individual body-fat gain and $\mathrm{P}_{\text {fast }}(r 0.54, P=0.065$, Fig. 6).

\section{DISCUSSION}

\section{Individual data}

Although at the start of the experiment, the weanling rats had almost identical body weights (CV 1.5\%), the individual response to fasting was variable. The CV of $\mathrm{N}$ loss on 


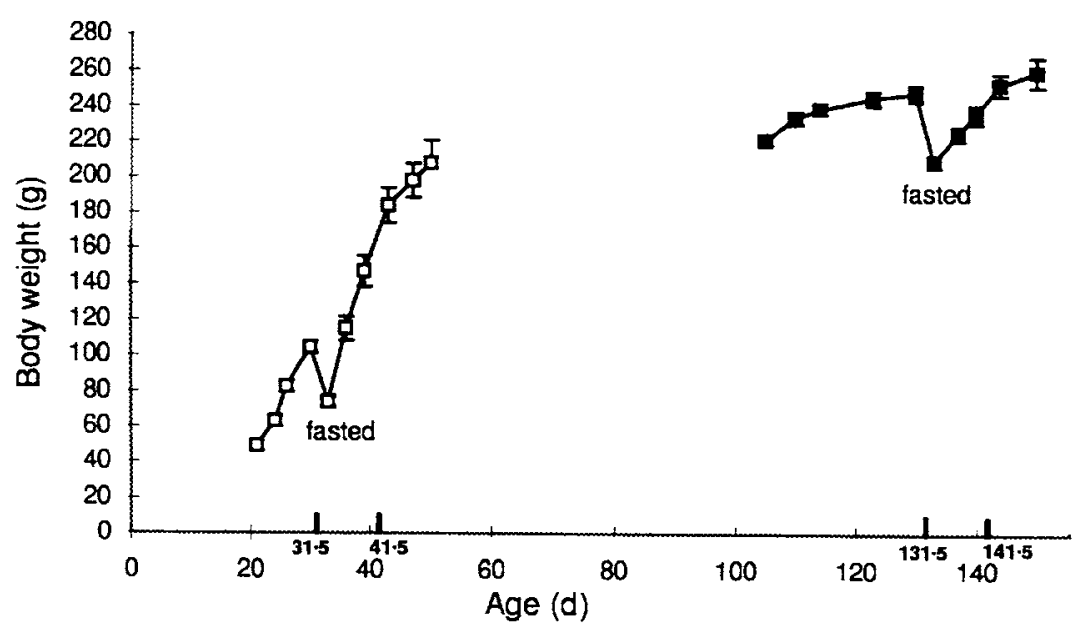

Fig. 4. Growth rates in weanling $(\square)$ and adult $(\square)$ rats before and after a $3 \mathrm{~d}$ fast. Values are means for eleven weanling and eight adult rats, with standard deviations represented by vertical bars. The highlighted age days on the horizontal axis represent the mid-points of the $P$ values measured.

Table 1. Energy and nitrogen balance of the fasted and refed states in weanling rats* (Mean values with their standard errors for eleven rats)

\begin{tabular}{|c|c|c|c|c|}
\hline \multirow[b]{3}{*}{ Variable } & \multicolumn{4}{|c|}{ Balance } \\
\hline & \multicolumn{2}{|c|}{ Fasted $(30-33 \mathrm{~d})$} & \multicolumn{2}{|c|}{ Refed $(33-50 \mathrm{~d})$} \\
\hline & Mean & SE & Mean & $\mathrm{SE}$ \\
\hline Food intake $(\mathrm{g})$ & - & - & 334.0 & 10.98 \\
\hline Weight loss or gain (g) & $-33 \cdot 3$ & 0.843 & +154.5 & 3.66 \\
\hline Energy loss or gain (kJ ME) & -209.7 & 5.56 & +1086.5 & $55 \cdot 28$ \\
\hline Urine energy loss $(\mathrm{kJ})$ & $-32 \cdot 8$ & 1.204 & - & - \\
\hline Protein energy gain (kJ ME) & - & - & +457.5 & $26 \cdot 14$ \\
\hline P ratio & 0.156 & 0.0035 & 0.421 & 0.0113 \\
\hline
\end{tabular}

ME, metabolizable energy.

* For details of procedures, see pp. 134-135.

fasting was $12 \%$ with $147 \mathrm{mg} / 3 \mathrm{~d}$ difference between the highest and lowest $\mathrm{N}$ loss. This degree of variability is comparable with the $\mathrm{CV}$ of about $15 \%$ reported for obligatory $\mathrm{N}$ loss in human subjects matched for age, sex and body weight (Bodwell et al. 1979). Adult animals also had similar body weights (CV 1.9\%) at the start of fasting; however, the $\mathrm{N}$ loss ranged from $532-590 \mathrm{mg} / 3 \mathrm{~d}$, with a CV of only $3.8 \%$.

\section{Relationship between $P_{\text {fast }}$ and $P_{\text {refed }}$}

An important stipulation of the standard Payne-Dugdale model of long-term body-weight regulation in adults, is that the value of the $P$ ratio should be the same, independently of the direction of change of energy balance. The results for individual adult rats, show that the $P_{\text {fast }}$ and $P_{\text {refed }}$ values were not significantly different, in agreement with the proposition of the Payne-Dugdale model. 


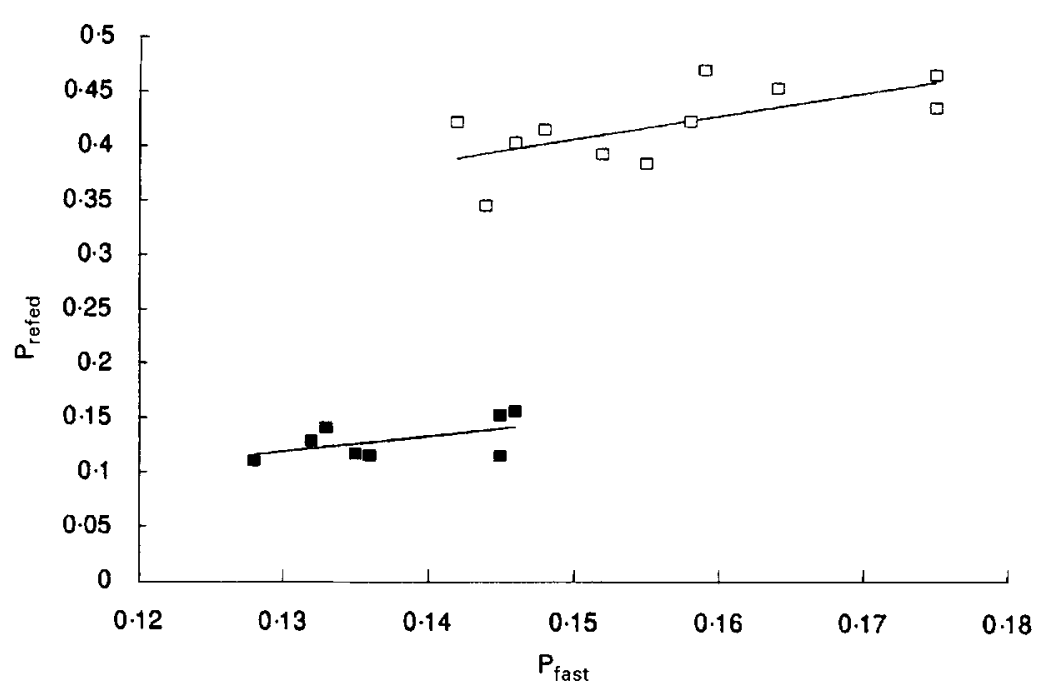

Fig. 5. Relationship between $P_{\text {fast }}$ (after $3 d$ fast) and $P_{\text {refed }}$ (after $17 \mathrm{~d}$ refeeding) in weanling $(\square)$ and adult $(\square)$ rats ( $r 0.6685, P<0.05$ for weanling rats; $r 0.5401$ for adult rats).

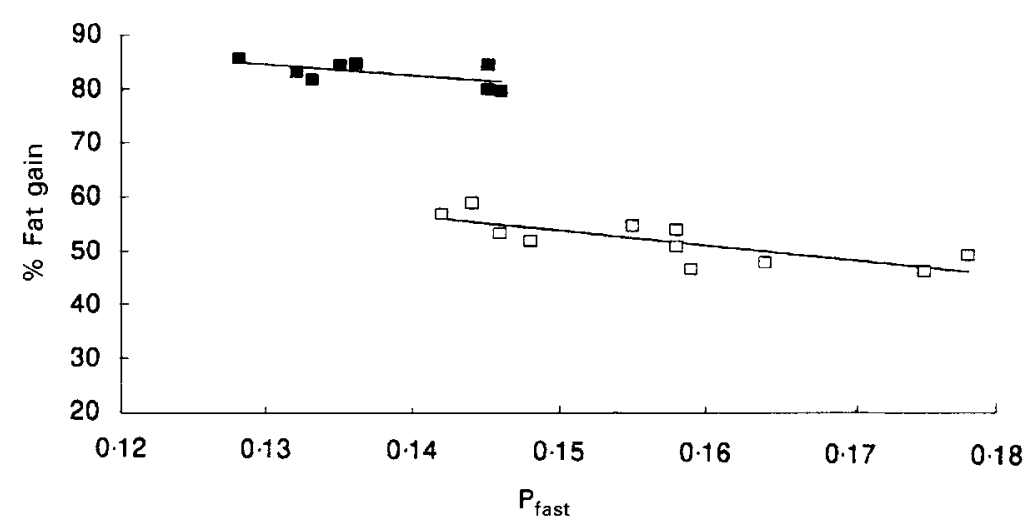

Fig. 6. Relationship between $P_{\text {fast }}$ and percentage body-fat gain in weanling ( $\square$ ) and adult ( $\square$ ) rats after a $3 d$ fast and $17 \mathrm{~d}$ refeeding ( $r 0.74, P<0.01$ for weanling rats; $r 0.542$ for adult rats).

The mean $\mathrm{P}_{\text {fast }}$ value in 30 -d-old rats $(0.156)$ was only slightly higher than for adult females reported earlier, indicating that about $16 \%$ of the total energy loss was derived from protein catabolism. The average $P_{\text {refed }}$ obtained was roughly 2.5 times the $P_{\text {fast }}$ value, so that $42 \%$ of any energy gained was associated with protein anabolism. It might be concluded from this that in the weanling rat the $P$ ratio is dependent on the plane of nutrition, with a rise in the proportion of lean tissue deposited during recovery, although this is in contrast to the suggestion of Dulloo et al. (1994) that compensatory growth involves partial preferential fat deposition. Alternatively, however, it could be argued that the design of the experiment described here, was such that the mid-point ages $(31.5$ and $41.5 \mathrm{~d}$ ) and the periods of measurement ( $3 \mathrm{~d}$ and $17 \mathrm{~d}$ ), cover such a large fraction of the growth cycle of the animals, that the differences are more likely to be age-related. Certainly, the direction and magnitude of these differences in $\mathrm{P}$ ratio are comparable with 
Table 2. Energy and nitrogen balance of the fasted and refed states in adult female rats* (Mean values with their standard deviations for eight rats)

\begin{tabular}{|c|c|c|c|c|}
\hline \multirow[b]{3}{*}{ Variable } & \multicolumn{4}{|c|}{ Balance } \\
\hline & \multicolumn{2}{|c|}{ Fasted $(130-133 d)$} & \multicolumn{2}{|c|}{ Refed (133-150d) } \\
\hline & Mean & SE & Mean & SE \\
\hline Food intake $(\mathrm{g})$ & - & - & 333.5 & 9.91 \\
\hline Weight loss or gain (g) & $-39 \cdot 0$ & 0.71 & +51.0 & 1.69 \\
\hline Energy loss or gain (kJ ME) & $-428 \cdot 0$ & 8.22 & +655.0 & $64 \cdot 35$ \\
\hline Urine energy loss $(\mathrm{kJ})$ & $-59 \cdot 0$ & 0.89 & - & - \\
\hline Protein energy gain ( $\mathrm{kJ} \mathrm{ME)}$ & - & - & +83.0 & 5.66 \\
\hline$P$ ratio & 0.138 & 0.002 & 0.130 & 0.006 \\
\hline
\end{tabular}

ME, metabolizable energy.

* For details of procedures, see pp. 135-136.

Table 3. $P_{\text {fast }}$ and $P_{\text {refed }}$ ratios in individual weanling and adult rats

\begin{tabular}{|c|c|c|c|c|c|c|c|c|}
\hline & \multicolumn{4}{|c|}{ Weanling rats } & \multicolumn{4}{|c|}{ Adult rats } \\
\hline & $P_{\text {fast }}$ & $P_{\text {refed }}$ & Rank $P_{\text {fast }}$ & Rank $P_{\text {refed }}$ & $\mathrm{P}_{\text {fast }}$ & $P_{\text {refed }}$ & Rank $\mathrm{P}_{\text {fast }}$ & Rank $P_{\text {refed }}$ \\
\hline & 0.142 & 0.423 & 1 & 6 & 0.128 & 0.11 & 1 & 1 \\
\hline & 0.144 & 0.346 & 2 & 1 & $0 \cdot 132$ & 0.13 & 2 & 5 \\
\hline & 0.146 & 0.404 & 3 & 4 & 0.133 & 0.141 & 3 & 6 \\
\hline & 0.148 & 0.416 & 4 & 5 & 0.135 & 0.117 & 4 & 4 \\
\hline & 0.152 & 0.394 & 5 & 3 & 0.136 & 0.116 & 5 & 3 \\
\hline & $0 \cdot 155$ & 0.386 & 6 & 2 & 0.145 & 0.153 & 6 & 7 \\
\hline & $0 \cdot 158$ & 0.424 & 7 & 7 & 0.145 & 0.115 & 7 & 2 \\
\hline & 0.159 & 0.471 & 8 & 11 & 0.146 & 0.156 & 8 & 8 \\
\hline & 0.164 & 0.455 & 9 & 9 & & & & \\
\hline & 0.175 & 0.469 & 10 & 10 & & & & \\
\hline & 0.175 & 0.438 & 11 & 8 & & & & \\
\hline Mean & $0 \cdot 156$ & 0.421 & & & 0.137 & 0.129 & & \\
\hline SD & 0.0115 & 0.0396 & & & 0.007 & 0.018 & & \\
\hline CV $(\%)$ & $7 \cdot 4$ & $9 \cdot 4$ & & & $5 \cdot 0$ & 14.0 & & \\
\hline
\end{tabular}

those shown to occur in human subjects between the ages of 6 months and 3 years (Dugdale \& Payne, 1975). Further research will be needed to resolve the relative significance of these two factors.

\section{Variability in $P$ ratio}

The results of the present study show that $P_{\text {fast }}$ values vary considerably between individuals (Table 3). When a group of animals were fasted, each responded differently, losing varying amounts of protein energy as a proportion of total energy, ranging from 11$18 \%$. This observed variability in $\mathrm{P}_{\text {fast }}$ in animals matched for body weight, is in accord with the proposition of the Payne-Dugdale model, that $P$ ratio values are characteristic of individuals. At the end of the refeeding period, a good correlation was evident between percentage body-fat gains and $P_{\text {fast }}$ values for both weanling and adult animals (Fig. 6), in agreement with the proposition of Dulloo et al. (1996) that the P value can be regarded as an expression of fat-lean compartmental 'memory'. 


\section{Inter-individual variation}

The Payne-Dugdale model was developed using $P$ ratio values derived from a wide range of human subjects, including overweight and 'thin' groups as well as those of average body build. The mean value for the adult human subjects was $0 \cdot 15$, very similar to that found for the adult female rats. However, the range observed in these animals was much smaller than that found in human subjects (0.01-0.4) (Payne \& Dugdale, 1977; Dulloo et al. 1996). This is hardly surprising, given the much greater degree of genetic homogeneity of the rats.

Finally, these results demonstrate the validity of using fasting urinary $\mathrm{N}$ loss and fasting body-weight loss, as proxies for protein energy and total body energy loss respectively. This establishes a rapid method for measuring $P$ values in experimental animals.

The authors would like to acknowledge the intellectual contribution made by the late John Rivers to the study of the $\mathrm{P}$ ratio. This work was supported by a grant from the Nestlé Foundation, Switzerland.

\section{REFERENCES}

Bodwell, C. E., Schuster, E. M., Kyle, E., Brooks, B., Womack, M., Steele, P. \& Ahrens, R. (1979). Obligatory urinary and faecal nitrogen losses in young women, older men, and young men and the factorial estimation of adult human protein requirements. American Journal of Clinical Nutrition 32, 2450-2459.

Bradstreet, R. (1965). The Kjeldahl Method for Organic Nitrogen. New York and London: Academic Press.

Donaldson, H. H. (1915). Memoirs of the Wistar Institute of Anatomy and Biology, vol 6. Philadelphia: Wistar Institute.

Dugdale, A. E. \& Payne, P. R. (1975). Pattern of fat and lean tissue deposition in children. Nature 256, $725-727$.

Dulloo, A. G., Henry, C. J. K., Ismail, M. N., Jacquet, J. \& Girardier, L. (1994). Predisposition to obesity in humans: an evolutionary advantage turned deleterious. International Journal of Food Sciences and Nutrition 45, 159-168.

Dulloo, A. G., Jacquet, J. \& Girardier, L. (1996). Autoregulation of body composition during weight recovery in humans: the Minnesota Experiment revisited. International Joumal of Obesity 20, 393-405.

Forbes, G. B. (1987). Lean body mass-body fat interrelationships in humans. Nutrition Reviews 45, $225-231$.

Garrow, J. S. (1974). Energy Balance and Obesity in Man. Amsterdam: North-Holland.

Garrow, J. S. (1978). Energy Balance and Obesity in Man. Amsterdam: North-Holland.

Henry, C. J. K., Rivers, J. P. W. \& Payne, P. R. (1988). Protein and energy metabolism in starvation reconsidered. European Journal of Clinical Nutrition 42, 543-549.

Keys, A., Brozek, J., Henchel, A., Michelsen, O. \& Taylor, H. L. (1950). The Biology of Human Starvation. Minnesota: University of Minnesota Press.

Kleiber, M. (1975). The Fire of Life. New York: Krieger.

Miller, D. S. \& Payne, P. R. (1959). A ballistic bomb calorimeter. British Joumal of Nutrition 13, 501.

Njaa, L. R. (1963). A Study on the Mitchell Method for Determination of the Biological Value of Protein. Bergen: Director of Fisheries.

Payne, P. R. \& Dugdale, A. E. (1977). A model for the prediction of energy balance and body weight. Annals of Human Biology 4, 525-535.

Prentice, A. M., Goldberg, G. R., Jebb, S. A., Black, A. E., Murgatroyd, P. R. \& Diaz, E. O. (1991). The physiological response to slimming. Proceedings of the Nutrition Society 50, 441-458.

Rothwell, N. J. \& Stock, M. J. (1981). Regulation of energy balance. Annual Review of Nutrition 1, $235-256$.

Swift, R. W. \& French, C. E. (1954). Energy Metabolism and Nutrition. Washington: Scarecrow. 